\title{
Oxytocin Hormone Induction on Milk Production in Relation to Dairy Kid Performance
}

\author{
Mas Yedi Sumaryadi*, Dadang Mulyadi Saleh, Aras Prasetiyo Nugroho, \\ Nu'man Hidayat and Chomsiatun Nurul Hidayah \\ Faculty of Animal Science, Jenderal Soedirman University, Purwokerto 53123, Jawa Tengah,Indonesia \\ *Corresponding author email: yedi.sumaryadi@yahoo.com
}

\begin{abstract}
The application of oxytocin induction to milk production in relation to the performance of kids in dairy goats had been carried out in the "PEGUMAS" dairy goat farmer group Gumelar District, Banyumas. This activity aimed to increase milk production and kid performance through the induction of the hormone oxytocin in dairy goats. The approach method was designed in two stages: the first stage carried out the socialization activities and demonstration of techniques for applying IPTEKS, and the second stage applied hormonal technology in the form of oxytocin hormone induction in dairy goats. The material used was dairy goat parity I aged 1.5 - 2 years allocated into 2 groups of 10 individuals each. Group I was dairy goat experiment not induced with the oxytocin hormone as the control. Group II was dairy goat experiment induced with the oxytocin hormone at a dose of $1 \mathrm{ml}(10 \mathrm{IU})$ intramuscularly before milking. Milk production was measured morning and evening as daily milk production in milliliters $(\mathrm{ml})$. Milk was given to the kid of each parent. The kid's performance was measured based on the daily weight gain of the kid during the study. Overall, the application of science and technology could be adopted by farmers, and oxytocin-induced dairy goat milk production $(503.2 \mathrm{ml})$ was significantly higher than control $(305.4 \mathrm{ml})$ with an increase of $64.77 \%$, with a positive level of correlation $(r=0.45)$ and contributed $19.83 \%$ to the kids daily body weight gain.
\end{abstract}

Keywords: milk yield, oxytocin, daily body weight gain, dairy goat

Abstrak. Aplikasi induksi hormon oksitosin terhadap produksi susu kaitannya dengan kinerja anak pada kambing perah telah dilaksanakan di kelompok peternak kambing perah "PEGUMAS" Kecamatan Gumelar, Banyumas. Kegiatan ini bertujuan untuk meningkatkan produksi susu dan kinerja anak melalui induksi hormon oksitosin pada kambing perah. Metode pendekatan yang digunakan dirancang menjadi dua tahap. Tahap pertama dilakukan kegiatan sosialisasi dan peragaan teknik penerapan IPTEKS. Tahap kedua mengaplikasikan teknologi hormonal berupa induksi hormon oksitosin pada kambing perah. Materi yang digunakan adalah kambing perah paritas I dengan umur 1,5-2 tahun yang dialokasikan menjadi 2 kelompok masing-masing 10 ekor. Kelompok I: kambing perah percobaan tidak diinduksi hormon oksitosin yang digunakan sebagai kontrol. Kelompok II: kambing perah percobaan diinduksi hormon oksitosin dengan dosis $1 \mathrm{ml}$ (10 IU) secara intramuskuler sebelum dilakukan pemerahan. Produksi susu diukur pagi dan sore hari sebagai produksi susu harian dalam satuan milliliter ( $\mathrm{ml}$ ). Air susu hasil pemerahan diberikan kepada anak dari masing-masing induk. Kinerja anak diukur berdasarkan pertambahan bobot badan anak harian selama kegiatan. Secara keseluruhan penerapan IPTEKS ini dapat diadopsi peternak dengan baik, dan produksi susu kambing perah yang diinduksi oksitosin $(503,2 \mathrm{ml})$ nyata lebih tinggi dibandingkan kontrol $(305,4 \mathrm{ml})$ dengan peningkatan sebesar $64,77 \%$, dan memiliki tingkat keeratan hubungan yang positif $(r=0,45)$ serta berkontribusi sebesar $19,83 \%$ terhadap pertambahan bobot badan harian anak.

Kata kunci: produksi susu, oksitosin, pertambahan bobot badan harian, kambing perah

\section{Introduction}

Improving population and productivity of dairy goat depends on calving process to breed healthy, weaned kids in one reproduction cycle. The potential improvement is attributed to the prolific nature of goat breeding - goat can breed one to four kids per delivery (Kaunang et al., 2012; Kurniasih et al., 2013). However, the success to raise the kids post-weaning is related to milk availability because milk is the primary source of nutrient for kids since delivery to preweaning, and it is essential for kids' growth and development. Malnutrition (milk) in preweaned kids would inhibit the growth and decrease immunity against disease, which eventually leads to mortality (Maylinda, 2010). 
This incident is prevalent the more kids delivered, the lower the body immune throughout the critical pre-weaning period. Therefore, only a few kids made it through the weaning period.

The increase of dairy goat's milk production for human consumption or the kids is below expectation. Previous studies reported that Etawah goat milk production varied around $0.67 \mathrm{~L}$ or $756.8 \mathrm{gram} / \mathrm{head} /$ day (Adriani et al., 2014), in a range of $0.20-1.3 \mathrm{l} /$ head/day (Marwah et al., 2010; Ramadhan et al., 2013; Astuti et al., 2017; Yustendi, 2017). The current problem is the high mortality rate in kids at an early age or post-weaning time which inhibits the increase of cattle population and productivity. The mortality rate could reach 12.5 - 30.0\% (Kaunang et al., 2012; Adriani et al., 2014), up to $28.57-57.14 \%$ (Kurniasih et al., 2013)

Milk production (milk let down) is naturally controlled by the oxytocin hormone from anterior hypophysis (Bhimte et al., 2018). However, environment-generated stress or milking disorder could inhibit the secretion of endogenous oxytocin through the circulation system; consequently, milk synthesis products in alveoli cells of milk gland is not entirely discharged and potentially causes mastitis disease. Previous studies showed that exogenous oxytocin injection before milking could improve milk production in cow (Belo and Bruckmaier, 2010; Rizzo et al., 2012) and buffaloes (Akhtar et al., 2012). Furthermore, it could increase milk production by $15.32 \%$ in oxytocin-induced sheep (Antonic et al., 2013). It provides an opportunity for further application to goat cattle, particularly dairy goat.

The result of this research focused on increasing milk production as well as improving the performance of weaned dairy kids. Additionally, milk is a potential food product for human consumption.

\section{Materials and Methods}

The research method applied a two-stage design. The first stage included socialization and exhibition of science-technology application technique. The second stage was hormonal technology application through oxytocin induction into dairy goats.

The materials used were dairy goats at parity I aged $1.5-2$ years old allocated into two groups, ten goats each. Group 1 was an experimental dairy goat without oxytocin induction as control groups, and Group II was experimental dairy goats induced with $1 \mathrm{~mL}$ (10 IU) oxytocin hormone intramuscularly before milking.

Milk production was measured in the morning and afternoon in $\mathrm{ml}$, then provided to kids in a separate cage from each mother. Kid performance was measured by body weight per time unit to obtain daily body weight gain throughout the study.

Success evaluation was conducted at the end of activity in two waves. The first wave was the farmers' level of adoption to apply sciencetechnology application, and the second wave was testing an oxytocin-induction application on milk production and kid performance.

\section{Results and Discussions}

Oxytocin induction to dairy goats was started with socialization to disseminate information regarding the activity materials and the exhibition of science-technology application for the dairy goat farmers. The result of socialization showed that $90 \%$ of the farmers could adopt the oxytocin induction to improve milk production and kid performance. Total milk production at the initial phase from Peranakan Etawah (PE), Saanen and Jawa Randu goats parity I aged $1.5-2$ years old is presented in Figure 1. 


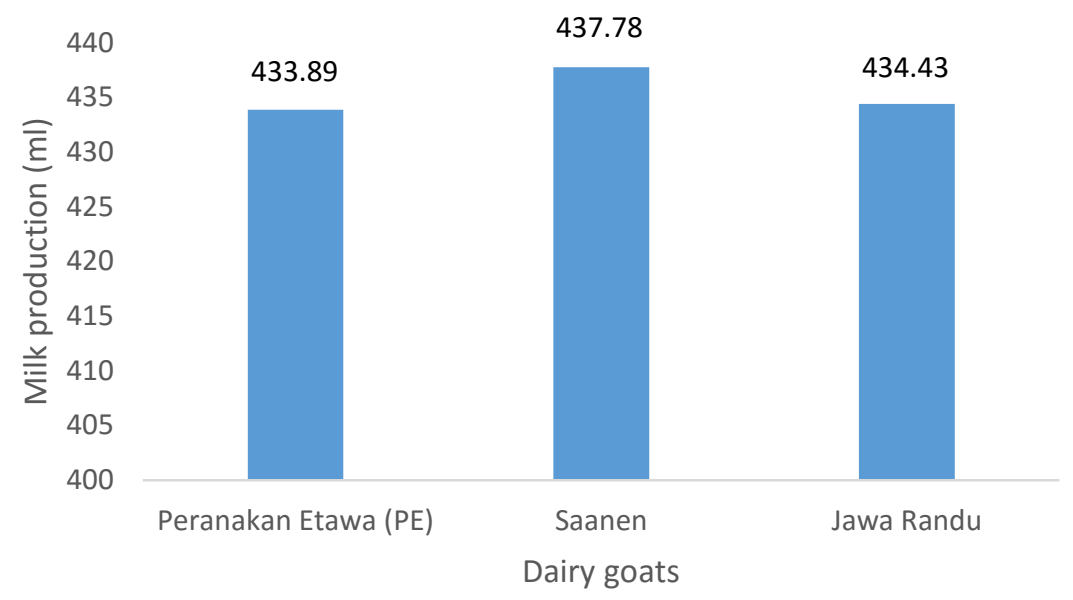

Figure 1 . Average daily milk production of dairy goats

The statistical analysis result showed that milk production was not significantly different $(P>0.05)$ across goat breeds ( $P E$, Saanen and Jawa Randu). The average milk production of dairy goat in this study was $435.37 \pm 248.09 \mathrm{ml}$ per head. The contributing factors may include similar age, parity, lactating period and breeding management in addition to the long adaptation to the local environment. However, the average milk production was higher than that of Etawah crossbred, Etawah-Kacang crossbred (PEK) and Etawah-Boer crossbred, namely $272.58 \pm 55.73,153.77 \pm 24.76$, and $174.61 \pm 35.22 \mathrm{ml}$, respectively (La Ode Nafiu et al., 2017). According to Hossain et al. (2018), cattle potential productivity is attributed to genetic factors, environmental factors and genetic-environment interaction. Also, goat productivity is influenced by climate, parity, litter size and lactating period (Sudewo et al., 2012). Milk production of dairy goats before and after oxytocin hormone induction measured in the morning and afternoon, as well as total milk production presented in Table 1.

Table 1 shows that oxytocin-induced dairy goats produced more milk in the morning and afternoon milking by 83.80 and $136.14 \%$, respectively, compared to non-induced dairy goats (control group). Statistical analysis result (see appendix) showed that oxytocin hormone significantly affected $(\mathrm{P}<0.05)$ total daily milk production. Therefore, the average daily milk production of oxytocin-induced dairy goats (503.2 $\mathrm{ml}$ ) was significantly higher than that of the control group $(305.4 \mathrm{ml})$ with a $64.77 \%$ increase in milk production. In line with the previous study, oxytocin injection in goat can increase milk production, especially milk fat (Nwosu et al., 2019). The current study showed a higher milk production in oxytocin-induced dairy goats than that in sheep (Antonic et al., 2013). Milk production is affected by total secretory cells in udder tissue, secretory cell activity to synthesize milk, and substrate availability for milk synthesis. Milk synthesis is conducted by secretory cells in milk gland using nutrition from feed (Kim and $\mathrm{Wu}, 2009$ ). Stimulation from milking is forwarded to the hypothalamus that produces oxytocin hormone. Furthermore, oxytocin stimulates contraction in the uterus wall (Heppelmann et al., 2018) and would trigger soft muscle around alveoli to contract and secretes milk by stimulating the ductus lactiferous contraction of milk gland (udder) to secrete milk (Masedunskas et al., 2017). 
Table 1. The average milk production of dairy goats induced with oxytocin hormone

\begin{tabular}{lcc}
\hline Variables & Control & Oxitocyn induction \\
\hline Milk production $(\mathrm{ml})$ & & \\
Morning & $358.0 \pm 274.9$ & $658.0 \pm 320.6$ \\
Afternoon & $147.5 \pm 99.5$ & $348.3 \pm 200.8$ \\
Total per day (ml/day) & $305.4 \pm 229.6^{\mathrm{a}}$ & $503.2 \pm 249.6^{\mathrm{b}}$ \\
\hline
\end{tabular}

$(a, b)$ Values bearing different superscript within rows show a significant difference $(P<0.05)$

The average daily milk production of dairy goats in this study was $435.37 \pm 248.09 \mathrm{ml}$ per head. It was higher than that of Etawah dairy goats (PE), Etawah-Kacang crossbred (PEK), and Etawah-Boer crossbred (PEB) namely $272.58 \pm$ $55.73,153.77 \pm 24.76$, and $174.61 \pm 35.22 \mathrm{ml}$, respectively (La Ode Nafiu et al., 2017). Daily body weight gain DWG) of kid consuming the milk of each mother was $(191.25 \pm 91.60 \mathrm{~g} /$ day. The DWG was higher than that reported by Ginting (2009) on Boer goats (118 g/day) and Kacang goats $(52-70 \mathrm{~g} /$ day $)$.

There is a significant $(\mathrm{P}<0.05)$ correlation between daily milk production and DWG with 0.45 coefficient correlation. The regression analysis result showed that daily milk production of dairy goats was significantly correlated $(P<0.05)$ with kid's daily weight gain (DWG) using an equation $Y=0.24+0.000217 x$ and 0.1983 coefficient of determination. It showed that kid's DWG was $19.83 \%$ affected by daily milk production offered to the kids from each mother.

Post-calving growth is significantly affected by milk consumption sufficiency before taking forage. According to Elkhair et al. (2017), kid's growth from the first month of age was solely dependent on the mother's milk - the higher the dependency, the lower milk production when the kids start eating solid food. Similarly, Htoo et al. (2018) reported that kids were dependent on their mother's milk up to 12 weeks post-calving before their rumens start to function and forage intake ensue. Pre-weaning growth was determined by birth weight, milk production, mother's welfare, total calves and their conditions, sex, genetic and breeding management (Maylinda, 2010).

\section{Conclusions}

Farmers well adopted Oxytocin hormone induction to improve milk production and kid performance in PEGUMAS association of dairy goat farmers. Oxytocin induction could increase milk production by $64.77 \%$, showed a close relationship ( $r=0.45$ ) and contributed $19.83 \%$ to kid's daily weight gain. However, this sciencetechnology application needs further investigation in the economic aspect and utilization of goat milk for human consumption.

\section{Acknowledgement}

The authors express their gratitude to the Chief of Research Centre and Community Service, Jenderal Soedirman University for the opportunity and research grant through DIPA funding Jenderal Soedirman University 2019 according to the Letter of Assignment to Community Service for implementing Science and Technology No: P/916/UN 23/ 14/PM/2019. We also thank Widi Utami Prahayuningtyas, a student of Magister Program for assisting community service, as well as the chief and members of PEGUMAS dairy goat farmer's community for the contribution to this study.

\section{References}

Adriani, S. N. and Fatati. 2014. Usaha IbIKK kambing Perah. Jurnal Pengabdian pada Masyarakat. 29(4):1 - 10 .

Akhtar, M. S., L. A. Lodhi, A. A. Farooq, M. M. Ayaz, M. Hussain, M. H. Lashari and Z. I. Chaudhary. 2012. Effect of oxytocin administration before milking on milk production, somatic cells count and fat contents in milk of Nili-Ravi Buffaloes. Pakistan Veterinary Journal. 32(3):435-437.

Antonic, J., V. Tancin, M. Uhrincat, L. Macuhova, J. Macuhova and L. Jackuliakova. 2013. The effect of exogenous oxytocin on milkability and milk 
composition in ewes differed in milk flow pattern. Small Ruminant Research. 113:254-257.

Astuti, P., H. Suripta and N. E. Sukarini. 2017. Produksi dan komposisi susu kambing Peranakan Ettawa memalui pemberian ekstrak meniran. Jurnal Ilmu-ilmu Pertanian. 1(2):82 - 87.

Belo, C. J. and R. M. Bruckmaier. 2010. Sutability of low-dosage oxytocin treatment to induce milk ejection in dairy cows. Journal of Dairy Science. 93:63-69.

Bhimte, A., N. S. Thakur, V. P. Maurya and G. Singh. 2018. Neurohormonal control of lactation and milk let-down in dairy animals. International Journal of Current Microbiology and Applied Sciences. 7(7):970-977.

Elkhair, A. A. M., I. A. Abdalla and G. H. El Obied. 2017. Effect of a home-made milk replacer on pre-weaning performance of Nubian male kids. Gezira J. of Agric. Sci. 15(2):107-118.

Ginting, S. P. 2009. Pedoman Teknis Pemeliharaan Induk dan Anak Kambing Pra-Sapih. Pusat Penelitian dan Pengembangan Peternakan, Loka Penelitian Kambing Potong. Sei Putih, Sumatera Utara. p:33-44.

Heppelmann, M., J. Volland, C. Pfarrer, M. Kietzmann, W. Baumer, S. Merbach, H. A. Schoon, O. Wellnitz, M. Schmicke, M. Hoedemarker and H. Bollwein. 2018. Effects of oxytocin and PGF2a on uterine contractility in cows with and without metritis - An in-vitro study. Animal Reproduction. 188:144-154.

Hossain, S. M. J., M. F. Afroz, A. K. F. H. Bhuiyan and M. A. Habib. 2018. Milk Production Performance of Red Chittagong Cattle Based on Phenotypic and Genetic Parameters. Glo. Adv. Res. J. Agric. Sci. 7(4):110-117.

Htoo, N. N., B. Zeshan, A. T. Khaing, T. Kyaw, E. A. Woldegiorgis and M. A. Khan. 2018. Creep Feeding Supplemented with Roughages Improve Rumen Morphology in Pre-Weaning Goat Kids. Pakistan Journal of Zoology. 50(2):703-709.

Kaunang, D., Suyadi and S. Wahyuningsih. 2012. Analisis litter size, bobot lahir dan bobot sapih hasil perkawinan kawin alam dan inseminasi buatan kambing Boer dan Peranakan Etawah. Jurnal Ilmu-ilmu Peternakan. 23(3):41- 46.

Kim, S. W. and G. Wu. 2009. Regulatory role for amino acids in mammary gland growth and milk synthesis. Amino Acids. 37: 89-95.

Kurniasih, N. N., A. M. Fuah and R. Priyanto. 2013. Karakteristik reproduksi dan perkembangan populasi kambing Peranakan Etawah di lahan pasca galian pasir. Jurnal IImu Produksi dan Teknologi Peternakan. 1(3):132 -137.

La Ode Nafiu, W. Kurniawan, P. N. Kusuma and M. Akramullah. 2017. Produktivitas dan Kualitas Susu Berdasarkan Bangsa dan Paritas kambing di Kabupaten Kolaka. Seminar Nasional Peternakan 3. $P: 19-28$.

Marwah, M. P., Y. Y. Suranindyah and T. W. Murti. 2010. Produksi dan komposisi susu kambing Peranakan Etawa yang diberi suplemen daun katuk (Sauropus androgynous L. Merr) pada awal masa laktasi. Buletin Peternakan. 54(2):94 - 102.

Masedunskas, A., Y. Chen, R. Stussman, R. Weigert, and I. H. Mather. 2017. Kinetics of milk lipid droplet transport, growth, and secretion revealed by intravital imaging: lipid droplet release is intermittently stimulated by oxytocin. MBoC. 28:935-946.

Maylinda. 2010. Pengantar Pemuliaan Ternak. Universitas Brawijaya Press. Malang.

Nwosu, E. U., I. J. James, O. Olowofeso, T. J. Williams and M. N. Bemji. 2019. Effects of oxytocin administration on milk yield and milk composition of West African dwarf does. Small Ruminant Research. 181:45-50.

Ramadhan, B. G., T. H. Suprayogi and A. Sustiyah. 2013. Tampilan produksi susu dan kadar lemak susu kambing Peranakan Etawa akibat pemberian pakan dengan imbangan hijauan dan konsentrat yang berbeda. Animal Agricultural Journal. 2(1):351 - 356 .

Rizzo, A., M. Mutinati, G. Minoia, M. Spedicato, M. Panteleo, and R. L. Sciorsci. 2012. The impact of oxytocin on the hemodynamic features of the milk vein in dairy cows: A color Doppler investigation. Research in Veterinary Science. 93:983-988.

Sudewo, A. T. A., S. A. Santosa and A. Susanto. 2012. Produktivitas kambing peranakan etawah berdasarkanlitter size, tipe kelahiran dan mortalitas di village breeding centre kabupaten banyumas. Prosiding Seminar Nasional: Pengembangan Sumber Daya Pedesaan dan Kearifan Lokal Berkelanjutan II. p:1-7.

Yustendi, D. 2017. Pemanfataan tanaman katuk (Sauropus androgynous L. Merr) dalam ransum untuk meningkatkan produksi susu kambing betina Peranakan Etawah. Jurnal Biology Education. 6(1):21 - 29. 